\title{
Entre jardins e flores, entre silêncio e transcendência: alguns percursos poéticos de Sophia de Mello Breyner Andresen
}

\section{Between gardens and flowers, between silence and transcendence: some poetic paths of Sophia de Mello Breyner Andresen}

Rodrigo Valverde Denubila

Universidade Estadual Paulista (UNESP), Araraquara, São Paulo / Brasil rodrigo.denubila@gmail.com

Resumo: Este estudo objetiva identificar a importância dos jardins e das flores para a construção do argumento lírico em alguns poemas de Sophia de Mello Breyner Andresen. Almeja igualmente destacar alguns temaschave andresenianos, entre eles, a investigação existencial. Percebe-se, assim, o jardim e as flores enquanto elementos utilizados para tecer indagações ontológicas, por conseguinte, fomentadores da busca de sentido. Da extensa obra da escritora, destacamos alguns poemas como "Árvores", "No tempo dividido" e As flores", que facultam a discussão de como as imagens da natureza permitem a ponderação sobre o sentido transcendente e o ontológico do ser dos entes humanos. Nesse percurso, revisitamos as percepções críticas acerca da autora realizadas por Jorge de Sena, Maria Andresen Sousa Tavares, Eduardo Lourenço, Eduardo Prado Coelho e Eucanaã Ferraz.

Palavras-chave: Sophia de Mello Breyner Andresen; jardins; flores.

Abstract: This study aims to identify the importance of gardens and flowers for the construction of the lyrical argument in some poems by Sophia de Mello Breyner Andresen. It also aims to highlight some 
Andresenian themes, among them, existential research. So, perceive the garden and the flowers as elements used to make ontological inquiries, therefore, fomenters of the search for meaning. From the author's extensive work, we highlight some poems such as "Árvores", "No tempo dividido" and "As flores", which provide a discussion of how the images of nature allow the pondering of the transcendent and ontological sense of the being of human beings. In this course, we review the critical perceptions about the author by Jorge de Sena, Maria Andresen Sousa Tavares, Eduardo Lourenço, Eduardo Prado Coelho and Eucanaã Ferraz.

Keywords: Sophia de Mello Breyner Andresen; gardens; flowers.

Data de submissão: 19 de julho de 2018

Data de aprovação: 17 de janeiro de 2019

A poeta portuguesa Sophia de Mello Breyner Andresen, autora dos importantes Coral (1950) e Geografia (1967), entre muitos outros, possui significativa produção literária caracterizada por uma arquitetura lírica que "exige empenho e gosto pelo risco" (FERRAZ, 2018, p. 17). Frisemos, neste momento, o termo risco, sendo esse entendido como a capacidade de fomentar interrogações que, ao longo da história, continuam sem respostas e a perturbar aqueles que as fazem. Durante seis décadas de produção estética, a autora, nascida em 1919, no Porto, cidade ao Norte de Portugal e marcada por estreitas ruas cravadas em pedra, como a do Gólgota, que levam ao rio Douro, em simbólico percurso, testemunhou mudanças intrínsecas e extrínsecas ao seu tempo histórico e suas respectivas axiologias à medida que refletia sobre temas de caráter universal, como os ligados à relação entre homem e transcendência.

Nessa via, na produção andreseniana, "a religiosidade é muito mais do que um artifício", conforme destaca Eucanaã Ferraz (2018, p. 29), em "Breve percurso rente ao mar", pois Sophia de Mello Breyner Andresen vale-se do aparato religioso para fomentar uma discussão de caráter global sobre a existência e seus caminhos, isto é, a poeta volta a esses componentes, por exemplo, do catolicismo não apenas como força imagética, importante na construção do poema, mas como instrumento dotado de intensidade semântica e argumentativa. Por trás dessa escolha, 
a capacidade de investigar sentidos. O mesmo acontece com o universo greco-romano - elementar na formação da autora - e, por sua vez, na mistura da tradição católica com a pagã, conforme realizado em "Ítaca", publicado em Geografia, em que a ilha de Ulysses torna-se a promessa de paraíso aos moldes cristãos:

$[\ldots]$

Quando o barco rolar na escuridão fechada

Estarás perdida no interior da noite no respirar do mar

Porque esta é a vigília de um segundo nascimento

O sol rente ao mar te acordará no intenso azul

Subirás devagar como os ressuscitados

Terás recuperado o teu selo a tua sabedoria inicial

Emergirás confirmada e reunida

Espantada e jovem como as estátuas arcaicas

Como os gestos enrolados ainda nas dobras do teu manto

(ANDRESEN, 2015, p. 558)

Ítaca configura-se como o local de volta do guerreiro ressuscitado - não reencarnado -, em seu segundo nascimento, após "rolar na escuridão fechada", ou seja, após a morte, sendo essa assinalada pelo inevitável "quando", advérbio que abre o poema e repetido no início do verso que alude à morte, assim como em outros poemas, conforme veremos adiante. Nesse paraíso, recupera-se a plenitude, porque não se está mais apartado do unitário, logo, o ser renascido emerge como uma estátua reunida, mas reunida com quem? Com si mesmo, portanto, fugindo da fragmentação interior, mas reunido semelhante com o unitário. Supera-se, dessa forma, a fragmentação oriunda da pós-queda adâmica causadora da separação do unitário.

$\mathrm{Na}$ esteira de Richard Zenith (2011), em "Uma cruz em Creta: a salvação sophiana", texto que aborda a poesia religiosa da poeta, entendese o sentimento pagão como aquele marcado pela presença da natureza; entretanto, como frisa o estudioso, Sophia não abandona a influência católica. Nesse escopo, o paraíso divino de base católica, poderoso por permitir acesso ao unitário, sendo essa sua grande marca, ganha densidade ao ser o local em que a natureza se apresenta em potência, quando o sol está rente ao mar e o céu de um "intenso azul". No entanto, até o quando do ser ressuscitado existe o presente do ser cindido. 
Nesse percurso, entre os mares das navegações emocionais e subjetivas marcados pelas contenção expressiva e os mares externoshistóricos qualificadores da cultura portuguesa e seu contato com o outro, conforme demonstra Navegações, publicado em 1983, avulta-se a percepção de uma consciência interrogativa e em crise, isto é, em busca de uma outra ordem, quer quando focaliza aspectos internos e poéticos, como o processo de construção do poema, quer, externos, como as consequências emocionais do Estado Novo português com o seu "velho abutre"1 e seus discursos que apequenam almas.

Sophia de Mello Breyner Andresen começa a publicar em 1940, quando seus primeiros versos saem nos Cadernos de Poesia. Nos catorze livros de poesia publicados ${ }^{2}$, sabendo que a escritora também produziu ensaios críticos e prosa, reconhece-se a força da produção andreseniana caracterizada pela percepção de uma profunda ausência que "se impõe como dimensão constitutiva do real", segundo leitura de Eduardo Prado Coelho (1972, p. 72), em "O real, a aliança e o excesso na poesia de Sophia de Mello Breyner Andresen”. Sophia faz parte da mesma geração de Eugénio de Andrade e Jorge de Sena, este revela explícita admiração pela percepção lírica da autora de Mar novo, como diz no ensaio "Escritoras na literatura portuguesa do séc. XX":

E chegamos às mulheres que cresceram sob o regime de Salazar, e temos que mencionar a maior de todas, Sophia de Mello Breyner Andresen. Uma aristocrata da mais velha cepa [...], uma das maiores poetas do século em português, e mãe de filhos, tornou-se activista política nos anos 50, e é actualmente deputada socialista na Assembleia Nacional (SENA, 1988, p. 151).

A importância da atitude testemunhal, por conseguinte, o ativismo da poeta destacado por Jorge de Sena (1988), a concordância e ponderação da autora acerca de seu tempo sócio-histórico, ganha força,

\footnotetext{
${ }^{1}$ Eis os já clássicos versos dedicados à descrição do ditador português Salazar: “O velho abutre é sábio e alisa as suas penas/ A podridão lhe agrada e seus discursos/ Têm o dom de tornar as almas mais pequenas" (ANDRESEN, 2015, p.489).

2 Poesia (1944), Dia do mar (1947), Coral (1950), No tempo dividido (1954), Mar novo (1958), O cristo cigano (1961), Livro sexto (1962), Geografia (1967), Dual (1972), O nome das coisas (1977), Navegações (1983), Ilhas (1989), Musa (1994) e O búzio de cós e outros poemas (1997).
} 
principalmente, a partir de Livro Sexto, conforme argumenta Luís Adriano Carlos (2002, p. 259):

A obra da autora evoluiu predominantemente de uma visão metafísica e panteísta, de Poesia e Mar Novo, para uma atitude testemunhal ou circunstancial, de Livro sexto em diante, unificadas numa recorrente busca de um sentido essencial e numa inconfundível uniformidade de tom e de expressão que alia o apagamento da confessionalidade romântica e a contenção formal dos grandes clássicos, a solenidade rítmica e a intensidade passional, a simplicidade aérea e a construção e a fluidez alusiva das imagens, o alegorismo prosopopeico e o metaformismo epigramático.

O termo "evolui" merece ressalva, pois traz a concepção de "melhoria", o que, sobremodo, não é o caso de uma poeta que estreia madura, segundo o entendimento de Eucanaã Ferraz (2018). Ao se debruçar na produção lírica andreseniana, torna-se necessário reconhecer tonalidades e preocupações inerentes à poeta, como a busca das relações entre as coisas e suas possíveis essências à proporção que o horizonte vivencial do sujeito poético ganha força a partir do momento que esse, por exemplo, olha um jardim e suas flores ao mesmo tempo que interroga o ser dos homens e busca traços de um todo originário.

Em vista disso, na poesia da autora de Coral, esses caminhos destacados por Luís Adriano Carlos (2002) não estão presos em si de forma estanque, mas se apresentam em interação que evidencia a "metamorfose fantástica das coisas e dos seres" (CARLOS, 2002, p. 259). Nesse percurso, cabe distinguir como a "visão metafísica e panteísta" dialoga com a "atitude testemunhal ou circunstancial" e ambas facultam uma poesia poderosa marcada pela reflexão acerca de aspectos da condição ontológica, mas também de dados sócio históricos. A poesia de Sophia de Mello Breyner Andresen, logo, não evoluiu, mas sim adensa, de forma racional e madura, a relação simbólica e associativa entre elementos diversos à proporção que, nesse caminhar, demarca ausências enquanto tenta estabelecer cadeias semânticas e, assim, a poeta parece querer mostrar o esforço de consciência necessário para estabelecer organizações e padrões por intermédio de uma poesia translúcida. Portanto, em Sophia de Mello Breyner Andresen, as palavras poéticas certeiras, densas e lapidadas arquitetam imagens claras e solares, em aparente nível, mas que, no profundo, ganham analíticas e semântica 
intensas por intermédio de elementos responsáveis pela visualidade e pela materialidade qualificadoras da composição andreseniana, como o mar, o jardim, o mundo grego e o ato poético apresentado como discurso, enquanto ars poética (FERRAZ, 2018; TAVARES, 2015).

Dentro do universo da poeta, como apresentado, parte considerável das imagens cerzidas remete ao universo clássico e à dicção desse. Ao falar sobre a produção da autora de Coral, Gastão Cruz (1973, p. 108) indica como "a temática grega (ou por extensão, latina) não é [...] decorativa nem folclórica". Nota-se como ideia similar foi reproduzida por Eucanaã Ferraz (2018) quando fala da religiosidade. Com essa predileção clássica, o referente direto e a conexão com a contemporaneidade parece que não se apresenta translucidamente e diretamente por mais que Sophia de Melo Breyner Andresen ofereça uma "sintaxe clara e direta" (FERRAZ, 2018, p. 17), por conseguinte, uma poesia sintaticamente limpa e contida que qualifica "o apagamento da confessionalidade romântica" (CARLOS, 2002, p. 259).

Nessa via, focalizando a importância da cultura helenística, interroguemos: o que está armado por trás do uso do mundo greco-latino? A principal diferença entre esse panteão e os seres humanos empíricos consiste em que aqueles não envelhecem e não morrem, por outro lado, ambos são marcados por faltas e afetos baixos como ciúmes, cobiça e inveja, logo, deuses e entes humanos estão permeados por falhas. Nesse quadro pagão, a divindade não provém da ausência de falhas de caráter, como acontece no ideário dos santos católicos após a canonização, mas sim da ausência de temporalidade. Em contraste com aqueles que não sofrem a ação do tempo, a poeta potencializa a temporalidade da condição humana, por sua vez, a efemeridade, a contingência e a mortalidade. Nesse percurso, vejamos como a problemática da temporalidade coaduna-se à analítica existencial nestes versos de "No tempo dividido" à proporção que o jardim ganha consistência poética e, dessa forma, deixa de ser um artifício visual para se tornar embebido de força lírica:

E agora ó Deuses que vos direi de mim?

Tardes inertes morrem no jardim

Esqueci-me de vós e sem memória

Caminho nos caminhos onde o tempo

Como um monstro a si próprio se devora

(ANDRESEN, 2015, p. 340, grifos nossos) 
O título do poema delimita um caminho reflexivo dual, isto é, o tempo divido entre o espaço sem tempo e o temporal, entre o tempo da vida e o da morte. Assim, o adjunto de lugar e, de certa forma, semelhantemente, de tempo intensifica a semântica da composição poética demarcada no título "No tempo dividido". O jardim sedimenta a percepção do tempo e da morte por intermédio das "tardes inertes [que] morrem no jardim"; inertes porque não se movimentam e inertes também porque não conseguem fugir da atuação do tempo, assim como tudo que existe. Contabiliza-se, assim, o jeito como o curto poema se fecha ponderando sobre o tempo e sua natureza. Cabe reconhecer, então, como o tempo em si mesmo não possui tempo, por conseguinte, representa uma grandeza absoluta. No entanto, esse se manifesta no mundo físico devido a sua ação nas coisas e nos seres que sentem os efeitos da temporalidade. O plano divino, por sua vez, não tem tempo ao ser eternidade, sendo esta entendida como ausência de temporalidade. Portanto, o tempo precisa da temporalidade inerente ao material para se manifestar, visto que os entes físicos estão apartados da eternidade até "quando o barco rolar na escuridão fechada" (ANDRESEN, 2015, p. 558). Até esse momento, a existência equivale a um processo de deixar de ser, logo, o existir representa um não-ser, pois os entes estão constantemente sendo até deixarem de ser.

Assim, a temporalidade qualifica a facticidade do existir, em que cada "caminho" existencial obrigatoriamente percorrido conduz ao fim, à morte, na expressão andreseniana, ao "monstro que a si próprio se devora". O tempo habita no mensurável do que existe; entretanto, quando elementos deixam de serem físicos, como demonstra a composição poética, o tempo acabou por devorar a si mesmo à medida que semelhantemente consumiu presenças. Ele acaba com a matéria, só que ao fazer isso semelhantemente finaliza a si mesmo e sua capacidade de manifestação. Ao ser "monstro que a si próprio se devora", o tempo se divide entre nascimento e morte, isto é, início e fim da temporalidade do que existe enquanto o ser percorre "o caminho nos caminhos onde o tempo" atua. Nessa linha reflexiva, outro sentido para o verbo dividir equivale a decompor, por sua vez, elementos decompostos são aqueles que sofreram a ação temporal.

A epistemologia poética de Sophia de Mello Breyner Andresen caminha entre a reflexão de base existencial-metafísica e a constatação da historicidade dos seres, isto é, a percepção da presença testemunhal 
de um ser que habita determinada faixa temporal. Nesse jogo, as flores guardam a "promessa antiga" do ser poder continuar a existir em uma "manhã futura":

\section{As flores}

Era preciso agradecer às flores

Terem guardado em si,

Límpida e pura,

Aquela promessa antiga

De uma manhã futura

(ANDRESEN, 2015, p. 341).

A partir da recorrência do motivo do jardim e das flores, percebe-se o movimento do argumento poético que vai do ôntico, ou seja, o dar-se do mundo ao ontológico, por consequência, a meditação sobre o sentido do ser e sua intrínseca temporalidade. Em uma materialidade apartada da transcendência, as flores, com sua opulência e visualidade, com sua pureza e limpidez, surgem como promessa, por outro lado, em outros jardins, nesse espaço, o eu poético de Sophia de Mello Breyner Andresen nota a potencialidade e inerência do silêncio, consequentemente, avultase a ausência elementar qualificadora da percepção poética da autora e reconhecida por Eduardo Prado Coelho (1972), como estes poderosos versos de "Eis-me", publicado em Livro sexto, também confirmam: "Mas o teu rosto está para além do tempo opaco/ E eu não habito os jardins do teu silêncio/Porque tu és de todos os ausentes o ausente" (ANDRESEN, 2015, p. 454, grifos nossos). Neste poema sem título publicado em Dia do mar, o jardim reaparece e novamente torna perceptível o silêncio:

Jardim verde e em flor, jardim de buxo

Onde o poente interminável arde

Enquanto bailam lentas as horas da tarde.

Os narcisos ondulam e o repuxo,

Voz onde o silêncio se embala,

Canta, murmura e fala

Dos paraísos desejados,

Cuja lembrança enche de bailados

A clara solidão das tuas ruas

(ANDRESEN, 2015, p. 136, grifos nossos). 
Para apontar a recorrência e importância desse aspecto da poética andreseniana, retomam-se estes versos de "O jardim e a noite":

\section{Mas sob o peso dos narcisos floridos \\ Calou-se a terra, \\ E sob o peso dos frutos ressequidos \\ Do presente \\ Calaram-se os meus sonhos perdidos}

(ANDRESEN, 2015, p. 67).

Uma atitude testemunhal marca o poema a partir do título "eis-me", ou seja, eis-me como sujeito e consciência mergulhada em interrogações diante de um silencioso jardim, em que está o ausente dos ausentes. Mas um jardim que pode ser habitado pelo sujeito ressuscitado. Logo, a ponderação de base metafísico-transcendental aproxima-se da atitude testemunhal apesar do afastamento de rompantes da confessionalidade. O sujeito poético de "Eis-me" qualifica o tempo como opaco. Tal determinação adensa as escuridões da consciência que não mais vislumbra a almejada visualidade e existência do rosto do ausente, o Ser dos seres, esse, no poema, definido pelo artigo - "o ausente" -, mas também indefinido pela incapacidade do ente humano de relacionar-se com aquele que habita os jardins silenciosos sem tempo que guardam "aquela promessa antiga/ de uma manhã futura", ou seja, de uma plenitude e de uma unidade, em que $o$ Sentido se materializa e afasta os sentidos. No caminho dos caminhos permeado por interrogações, cai-se no silêncio e na incapacidade de transmitir e de estabelecer nexos coerentes semânticos à proporção que os narcisos, em dois momentos de poemas distintos, ganham densidade simbólica.

Nos versos destacados de "Eis-me" há um jardim silencioso, uma outra "Ítaca" que não se apresenta e, por conseguinte, não permite as palavras denotadoras de percursos transcendentes e ontológicos, logo, de verdades últimas. Resta, por sua vez, as de expressão poética e a sua capacidade de materializar limites e quietudes. Nessa caminhada, percebe-se que a raiz que ligava os seres ao divino, sendo este responsável pelo caráter de verdade, foi cortada, como demonstram estes versos: "A raiz da paisagem foi cortada. /Tudo flutua ausente e dividido, / Tudo flutua sem nome e sem ruído" (ANDRESEN, 2015, p. 284). A capacidade de nomear, de estabelecer sentidos pelas palavras, sendo a percepção dessa atitude lida como "presente" divino dado ao homem, em função da sua 
imagem e semelhança com o transcendente, sofre intensa ruptura com o avanço da consciência moderna, ou seja, com a percepção de que o homem descende do macaco e não de Deus, assim como possui um substrato inconsciente e incontrolável mais forte do que o consciente.

De acordo com o Dicionário de símbolos, de Jean Chevalier e Alain Gheerbrant (2009, p. 512), o jardim simbolicamente pode ser interpretado como um "convite à restauração da natureza original do ser" - essa pode ser entendida como o momento em que o homem surge, retomando os versos de "Ítaca", recuperando a "sabedoria inicial" (ANDRESEN, 2015, p. 558), assim como confirmado e reunido. No entanto, como frisado, esses jardins são percebidos pela consciência poética como silenciosos e nessa mudez o sujeito lírico reconhece um adeus, como acontece neste poema intitulado "Árvores":

Árvores negras que falais ao meu ouvido,
Folhas que não dormis, cheias de febre,
Que adeus é este adeus que me despede
E este pedido sem fim que o vento perde
E esta voz que implora, implora sempre
Sem que ninguém lhe tenha respondido?...

(ANDRESEN, 2015, p. 291)

Adeus a quê? Ao sentido possível designado pelo unitário e escatológico, quer inicialmente focado no jardim do Paraíso, isto é, na força transcendental, em que as coisas são a si mesmas, quer aos percursos dos rumos da História de base hegeliana, ou seja, da trajetória humana rumo ao Absoluto. Cabe destacar, nesse contexto, o entendimento de Gianni Vattimo (2002, p. VI) sobre a modernidade para quem essa "pode caracterizar-se, de fato, por ser dominada pela ideia da história do pensamento como uma 'iluminação' progressiva, que se desenvolve com base na apropriação e reapropriação cada vez mais plena dos 'fundamentos"'. Com o avanço da consciência moderna, marcada ontologicamente pela percepção da ausência, sentimento reconhecido na poesia de Sophia de Mello Breyner Andresen, conforme frisa Eduardo Prado Coelho (1972), o valor último do ser não se determina mais por uma dimensão metafísica-transcendente, por mais que essa seja desejada e buscada a partir da visualidade dos jardins e das flores e sua possível capacidade de revelação existencial. 
A modernidade social, por sua vez, com o advento do nazismo, que transformou melhorias tecnológicas e científicas em mecanismos de barbárie, igualmente, causa profunda fratura na consciência contemporânea. Na modernidade social, iniciada a partir do século XVI, o homem se afasta de deus e se aproxima do homem, ou seja, qualifica esse período uma maior importância dada ao homem e seu desejo de domínio da natureza e seus gigantes Adamastores. Do mesmo modo, inicia-se uma séria de alterações nas relações sociais, políticas, econômicas e religiosas como, por exemplo, a modificação do sistema medieval alicerçado na centralidade da figura do rei e no poderio da Igreja católica para um processo de laicização do estado e mudança nos regimes políticos com base em revoluções sociais como, por exemplo, a Francesa. Tudo isso consequentemente transforma a consciência dos seres humanos que faculta a transformação de um modo social e psíquico de ser "medieval" para um "moderno". Entretanto, há consequências como o silêncio do ausente e a manifestação da percepção da humanidade caminhava em linha ascendente.

Após a falência da perspectiva religiosa e histórica, o pensamento ocidental focalizava e acreditava na científica como mecanismo apto a estabelecer o paraíso terrestre, porém, as consequências emocionais após a II Grande Guerra criam um outro vácuo que intensifica o valor do silêncio, a afastamento do ausente dos ausentes, em outros termos, a quebra com a raiz primordial à medida que se exacerba um adeus e um pedido de explicações que o vento perde. Por diferentes aspectos, os "paraísos desejados" (ANDRESEN, 2015, p. 136) não acontecem. No entanto, por outro lado, após a interrogação, têm-se as silenciosas possibilidades permitidas pelo uso das reticências precisando a continuidade do ciclo entre perguntas e silêncios, entre esperança e desamparo.

Nessa trajetória, sobra, assim, a consciência poética apartada da verdade e da capacidade de reconhecer a relação unívoca e não plural entre as palavras e as coisas, entre a substância e a matéria. Assim, pelos percursos do sujeito poético entre jardins e flores, entre silêncio e transcendência, formula-se, da mesma forma, o jogo entre presença e ausência, sendo que essas ganham maior força e densidade semântica através da intensificação do estado do ausente que se cala, pois "a intensidade excessiva da presença das coisas aponta o fogo devorador da ausência que as ilumina" (COELHO, 1972, p. 231). Na esteira desse pensamento, Eduardo Lourenço (1975, p.II), em "Para um retrato de 
Sophia", assinala que "o natural êxtase ou terrífica anunciação com que recebe a revelação do original esplendor do mundo ou a sua súbita ocultação" qualificam a percepção da autora de Ilhas. Visualidade e ocultação, busca do real e silêncio do ausente dos ausentes, nota-se, nesse percurso, semelhante, a "quebra da hierarquia entre o humano e o natural" (FERRAZ, 2018, p. 21). Hierarquia cindida com a alteração na relação harmônica com a natureza balizada pelo paganismo, consoante com Richard Zenith (2011), e hierarquia igualmente rompida na modernidade social pela centralidade do homem.

A poesia de Sophia de Mello Breyner Andresen, por meio da visualidade, assim como do diálogo com diferentes tradições, interroga a face oculta ou silenciosa das coisas. Existir, em sua etimologia, remete a estar fora de si, lançado em projetos, à abertura, à possibilidade de o homem poder vir a ser si mesmo. Nessa medida, a viabilidade de algo poder vir a ser si mesmo está determinada durante certa temporalidade, logo, são históricas, por conseguinte, finitas e temporais, mas, como apresentado pelo sujeito poético, o tempo a si mesmo se devora e as condições de realmente conhecer as coisas em sua verdade e a si ocupam certas faixas temporaisexistenciais. Essa consciência temporal gera angústias e contradições intensificadas pela consciência moderna apartada do transcendente.

Eduardo Prado Coelho (1972, p. 226) evidencia como a poeta "expressa uma exigência radical: ver uma coisa e procurar ver a totalidade onde essa coisa é". Cabe interrogar aspectos do verbo ser conjugado e destacado pelo crítico português, o que faculta outra interrogação: o que é ser? A semântica do ser, em sua base filosófica, segundo Nicola Abbagnano (2012), permite tanto o estabelecimento de predicados, quanto a busca do sentido existencial. Todavia, um dado tem conexão com o outro, uma vez que certos predicativos geram a forma como o ser dos entes é entendido e, dessa forma, a determinação da verdade sobre eles. Um predicado pode determinar o valor e sentido existencial daquele ente e, assim, o estabelecimento da verdade sobre aquele ente. A verdade, portanto, seria a clara relação entre as palavras e as coisas; no entanto, a produção poética andreseniana faculta a ruptura com a raiz primordial à medida que se revela historicidades e arbitrariedades enquanto tenta ver totalidades à medida que usa da linguagem.

Nessa linha argumentativa, a inquirição “o que é” pede pela linguagem, haja vista que esta é responsável quer pelo aspecto predicativo, quer pelo existencial do ser dos entes. Avulta-se a modificação no modo 
como a verdade era estabelecida, como o saber era delimitado antes da alteração do estatuto da linguagem e, por consequência, da reflexão de como é possível pensar o sentido do ser, da verdade. Não é gratuito, portanto, que o filósofo e crítico literário George Steiner (1993), em Presenças reais, reconhece que toda reflexão séria sobre a linguagem simboliza uma ponderação teológica ligada ao princípio transcendente de toda a verdade e do Sentido, assim como análoga a moderna Nostalgia do absoluto, título de outra obra desse pensador. Pode-se ilustrar essa ideia a partir destes magistrais versos de "Coral": "Ia e vinha/E a cada coisa perguntava/Que nome tinha” (ANDRESEN, 2015, p. 255).

$\mathrm{O}$ afastamento do homem de deus qualificador da modernidade social respinga na relação com a linguagem, pois se percebe a ausência de um ponto seguro de referência, logo, o caráter arbitrário dessa, o que evidencia a forma como a unidade qualifica o status daquele que é unitário, entretanto, na excrescência do silêncio do ausente, sobra a historicidade do ser e um conjunto de ruínas. Pelas percepções facultadas pela visualidade da opulência de jardins e de flores existe a ciência de que a relação entre as palavras e as coisas não é "límpida e pura" (ANDRESEN, 2015, p. 341), mas sim opaca, retomando os adjetivos utilizados pelo eu poético. Desse modo, segundo Eucanaã Ferraz (2018, p.19), o lirismo da autora de Navegações demonstra a força de uma "consciência crítica vigilante" que "nunca desviou das ruínas do mundo". Todavia, nessa contemplação, o sujeito poético encontra as reais e as metafóricas "ruínas do mundo", com os seus "velhos abutres", transcendentes silêncios e ausências. No entanto, "apesar das ruínas e da morte" (ANDRESEN, 2015, p. 61), verso que abre o primeiro poema do primeiro livro publicado por Sophia, qual seja, Poesia, em 1944, as mãos da poeta "nunca ficam vazias" (ANDRESEN, 2015, p. 61), pois o sujeito lírico é dotado do ato de ver e, no caso de Sophia de Mello Breyner Andresen, esse sentido ganha densidade pela necessidade, retomando Eduardo Prado Coelho (1972), de ver totalidades apesar da consciência do silêncio, como revela a percepção do jardim, sendo esse, como apresentado, entendido como símbolo da possibilidade de "restauração da natureza original do ser" (CHEVALIER; GHEERBRANT, 2009, p. 512). No entanto, a ciência dessa possibilidade conduz à construção de poemas, logo, ao ato poético simbolizado pelas "mãos que não ficam vazias", em outros termos, a construção de outros jardins, no caso em questão, os de natureza literária. 
A visualidade consiste em um dos elementos caros à cultura grega, conforme argumenta Alfredo Bosi (1988, p. 65), em seu ensaio "Fenomenologia do olhar": "A cultura grega, acentuadamente plástica, enlaçava pelos fios da linguagem o ver ao pensar". Gerd A. Bornheim (1988, p. 89) semelhantemente reconhece essa particularidade da cultura grega que aproxima "o verbo ver com o ato do conhecimento". Interligando esses entendimentos ao universo poético andreseniano, Gastão Cruz (1973, p. 107-108) assinala: "A lição dos gregos, que nos ensinaram a olhar, presente, desde o primeiro livro, na poesia de Sophia de Mello Breyner, é repetidamente invocada nessa homenagem à Grécia sem paralelo em toda a poesia portuguesa". Uma "obstinada fé na imanência", consoante com a exegese de Maria Andresen Sousa Tavares (2015, p. 45), marca a concepção lírica da poeta, o que dialoga com importância atribuída ao olhar.

No juízo lírico da autora de Dual, o "ato do conhecimento" é "ao mesmo tempo atónico e luminoso do essencial, comunhão silenciosa e sem cessar reverberante com tudo aquilo que, por original, a reflexão e seus intérminos labirintos deixarão intactos" (LOURENÇO, 1975, p. I). A luminosidade e visualidade do jardim - a ponto de criarem uma "mitologia do «jardim cercado»" (TAVARES, 2015, p. 11) - causam $a$ percepção do assombro e o conhecimento do espanto, ambos operados pelas aporéticas interrogações facultadas pela observação do jardim pelo sujeito poético. Ou seja, do visual, do que é inerente ao mundo material e concreto, há um salto para a inquirição de ordem existencial e metafísica por meio da apreensão operada pela visualidade do jardim e das flores como aparatos aptos a estabelecer uma religação com universo pagão, isto é, com a hierarquia harmônica anterior e, assim, a natureza apresentase como mecanismos privilegiado de interrogação existencial. Nessa "fé na imanência", o mar ocupa importante espaço, mas também, em contraponto complementar, os jardins e os elementos que os compõem.

Esse momento lírico que aspira à religação, por sua vez, a respostas adensa a percepção da ausência e a certeza da temporalidade e, com essa escolha, intensifica-se o "mistério repassado de claridade na produção de Sophia de Mello Breyner Andresen, segundo Eduardo Lourenço (1975, p. I). Pela expressão estética-literária contida e distante de uma confessionalidade explícita, há intenso percurso de descoberta do ser e do estar no mundo temporal aliados à angustiante certeza de um "Quando", título de um dos poemas de Dia do mar: 


\section{Quando}

Quando o meu corpo apodrecer e eu for morta

Continuará o jardim, o céu e o mar,

E como hoje igualmente hão-de bailar

As quatro estações à minha porta.

Outros em Abril passarão no pomar

Em que tantas vezes passei,

Haverá longos poentes sobre o mar,

Outros amarão as coisas que eu amei.

Será o mesmo brilho, a mesma festa,

Será o mesmo jardim à minha porta,

E os cabelos doirados da floresta,

Como se eu não estivesse morta

(ANDRESEN, 2015, p. 191).

Substratos de outros poemas reaparecem em "Quando", o que conduz à constatação da reincidência do jardim como local privilegiado de percepção de ciclos, entre eles, o existencial, sendo esse assinalado pelo eu poético e da mesma forma qualificador de outros seres humanos frente à aparente atemporalidade da natureza, mais próxima de um modo de ser divino. Os diferentes modos de percepção do jardim qualificadores da poética andreseniana podem ser transplantados para a expressão "apesar de" que, de certa forma, ilustra o poema "Quando", isto é, apesar da morte, a continuidade do jardim, do céu e do mar e de outros. Em razão da força dessa expressão, quando vislumbra a poesia de Sophia de Mello Breyner Andresen, Eucanaã Ferraz (2018, p. 19) entende que: "A escrita de Sophia nunca deixará de partir desse 'apesar de"”.

Entretanto, nesse poema, há dois tempos: um da continuidade do jardim e outro da temporalidade do ente humano. O verbo ser no futuro do presente do modo indicativo, iniciando os dois últimos versos da última estrofe, demarca um tom de certeza e continuidade, contudo, indiretamente, também uma tonalidade de interrogação: Será o mesmo brilho, a mesma festa? Será o mesmo jardim à minha porta? E, assim, alguns questionamentos são permitidos, entre eles: Outros seres perceberão e enxergarão o êxtase dessa visualidade como se o eu poético não estivesse morto ou precisam desse olhar lírico plasmado em poema para notá-lo? Em outros termos, pelo trabalho estético das 
mãos que não ficaram vazias e produziam poemas, apesar das ruínas e da morte, no momento da leitura, a poeta morta volta a viver? Essa pergunta ao molde proustiano proporciona duplo caminho, isto é, uma senda que interroga a condição existencial de formal geral e outra que inquiri a condição do produtor de objetos estéticos, entre eles, o poema. O último verso fecha com a flexão no feminino do termo "morta", o que subjetiva essa peça lírica.

Por intermédio dessas interrogações e da imagística dos poemas apresentados, vislumbra-se como a consciência poética percebe o mundo com o "seu esplendor da presença das coisas" (ANDRESEN, 2015, p. 893), conforme descreve a autora em sua "Arte poética III". Presença entendida como mecanismo elementar para interrogar o Ser e a temporalidade do ser dos entes humanos, cada um marcado pelo seu inquestionável e inevitável quando. Portanto, a visualidade do jardim aproxima-se da percepção da temporalidade, por conseguinte, da morte, logo, a constatação da forma como "com frequência, a pesada consciência da morte" trespassa o lirismo da autora de Mar novo, de acordo com Maria Andresen Sousa Tavares (2015, p. 10). Reforçando esse elemento e preocupação afetiva, no poema "A Casa", publicado em Dual, a imagem da morte aliada ao jardim reaparece:
A casa que eu amei foi destroçada
A morte caminha no sossego do jardim
A vida sussurrada na folhagem
Subitamente quebrou-se não é minha

(ANDRESEN, 2015, p. 581).

"A morte caminha no sossego do jardim", logo, esse a guarda, assim como guarda as "árvores negras" (ANDRESEN, 2015, p. 291) e as "folhas [...] cheias de febre" (ANDRESEN, 2015, p. 291). No entanto, de forma complementar, existe a "vida sussurrada na folhagem" - vida que leva ao ato poético? - e as flores com sua promessa de uma outra manhã para diferentes outros após o "poente interminável" (ANDRESEN, 2015, p. 136). Interminável, porque diferentes ciclos estão presentes dentro do maior de todos chamado universo, interminável em sua extensão, mas que teve o seu início e será que terá o seu fim, o poente dos poentes? Os jardins simbolicamente também funcionam como "um resumo do universo" (CHEVALIER; GHEERBRANT, 2009, p. 514), além da promessa de "restauração da natureza original do ser" (CHEVALIER; 
GHEERBRANT, 2009, p. 512), então, a presença da maior grandeza existente também funciona para apontar a relatividade do tempo humano, assim como frisa a pequenez e as lacunas do conhecimento dos homens sobre as suas origens, bem como permitem, novamente, interrogações de base teológicas. A flora, portanto, funciona como aparelho para mascarar os afetos e os questionamentos que marcam a consciência lírica andreseniana e sua aparente ausência de confessionalidade, que opera, como frisou Eduardo Lourenço (1975), entre o atônito e o esplendor, outra maneira de entender o sentido fundante de um "apesar de", reconhecido por Eucanaã Ferraz (2018).

Assim, entre as aporéticas angústias e o desejo de plenitude, conforme acontece na dualidade demarcada no título do poema "O jardim e a noite", publicado em Poesia, diferentes peças líricas nascem com base nas dúvidas de um sujeito poético que interroga e se interroga à medida que olha ou atravessa o "jardim solitário e sem luta/ [...] para tentar como outrora/unir a minha alma à tua" (ANDRESEN, 2015, p. 67). Outrora quando? Unir a alma do sujeito poético com a de quem? A um possível Ser dos seres que outrora existiu ou irá existir em algum outro jardim do tempo sem tempo. Tal interrogação não pode ser respondida sem presença da religião e a constatação, retomando o início desta discussão, de como ela permite sendas interpretativas ao ser "muito mais do que um artifício" de expressão lírica.

No entanto, a estrutura do pensamento moderno/contemporâneo qualificadora do tempo histórico de Sophia de Mello Breyner Andresen quebrou a raiz, o seu laço com a transcendência, logo, destaca Eduardo Prado Coelho (1972, p. 227-228), "não poderemos entender a poesia de Sophia se nos esquecermos que ela é uma poesia da separação: a aliança que nos ligava às coisas e estabelecia o reino soberano da plenitude é uma aliança quebrada, dispersa, esquecida". Silêncio, separação e falta de valor escatológico destacam o afastamento de um todo originário e do tempo sem tempo. Nesse ínterim, as flores conotam importante lembrete de uma condição fática e ontológica apartada do "tempo luminoso", como expressa este poema sem título publicado em No tempo divido:

A liberdade que dos deuses eu esperava

Quebrou-se. As rosas que eu colhia,

Transparentes no tempo luminoso,

Morreram com o tempo que as abria

(ANDRESEN, 2015, p. 325). 
Essa curta e intensa peça lírica enfatiza a negação do acesso ao princípio transcendente que guarda a verdade, ou seja, o valor e o sentido do unitário qualificador dos deuses e apto a suprimir a multiplicidade e as lacunas inerentes ao ato de conhecer, conforme frisa Eduardo Lourenço (1975) ao discutir a poesia de Sophia de Mello Breyner Andresen. Essa liberdade, percebida como unidade fundamental, quebrou-se pelos motivos expostos ao longo desta discussão e, de forma magistral, logo na sequência dessa constatação surge, carregada de densidade semântica, a imagem da rosa transparente e viva contraposta a outra rosa que perde as pétalas. Ou seja, diante da constatação da impossibilidade do eu em usufruir da liberdade dos deuses, tem-se a visualidade da rosa que morre pela ação do tempo que a abre e, por conseguinte, a faz perder as pétalas.

Frisa-se a rosa na qualidade de "símbolo de regeneração" (CHEVALIER; GHEERBRANT, 2009, p. 789). No entanto, nesse poema, a morte dessa flor conota a falência do desejo do eu de regeneração, por conseguinte, de encontro de si com a sua essência fundante sobrando, portanto, a fé na capacidade de isso acontecer em um outro jardim onde o ser pode ressuscitar. Nessa "poesia da separação" (COELHO, 1972, p. 227) entre o plano das rosas transparentes e o plano das rosas que morrem, novamente, o tempo demarca a temporalidade das coisas ao eliminar essas flores à medida que quebra a liberdade esperada pelo eu poético de, na temporalidade de sua existência, encontrar a plenitude e a regeneração de sua condição insuficiente.

Desses percursos contemplativos, distingue-se o fraturado ato de conhecimento e as dúvidas levantadas pelo sujeito poético de Sophia de Mello Breyner Andresen frente aos jardins e flores qualificadores dessa produção lírica. Tais elementos, assim como com a religiosidade, estão além da plasticidade e da visualidade, logo, "são muito mais do que um artifício" (FERRAZ, 2018, p. 29), na medida em que chamam considerações sobre a temporalidade dos seres e seu intrínseco processo existencial, bem como a relação com a capacidade de conhecer e com a transcendência. Sobressai-se, portanto, a importância, além do mar, dos jardins e das flores enquanto meios fundamentais para dar densidade ao raciocínio construído em poemas diversos. 


\section{Referências}

ABBAGNANO, N. Dicionário de filosofia. 6. ed. Tradução de Alfredo Bosi. São Paulo: WMF Martins Fontes, 2012.

ANDRESEN, S. de M. B. Obra poética. Porto: Assírio \& Alvim, 2015.

BORNHEIM, G. A. As metamorfoses do olhar. In: NOVAES, A. (Org.). O Olhar. São Paulo: Companhia das Letras, 1988. p. 89-93.

BOSI, A. Fenomenologia do olhar. In: NOVAES, A. (Org.). O Olhar. São Paulo: Companhia das Letras, 1988. p. 65-87.

CARLOS, L. A. Sophia de Mello Breyner Andesen. In: LOPES, Ó.; MARINHO, M. de F. (Org.). História da literatura portuguesa: as correntes contemporâneas. Porto: Asa, 2002. p. 259-262.

CHEVALIER, J.; GHEEBRANT, A. Dicionário de símbolos. Tradução de Vera da Costa e Silva. 23. ed. Rio de Janeiro: José Olympio, 2009.

COELHO, E. P. O real, a aliança e o excesso na poesia de Sophia de Mello Breyner Andresen. In:

Portucalense, 1972. p. 225-232. - A palavra sobre a palavra. Porto:

CRUZ, G. Sophia de Mello Breyner Andresen. In: portuguesa hoje. Lisboa: Platano Editora, 1973. p. 107-110. . A poesia

FERRAZ, E. Breve percurso rente ao mar. In: ANDRESEN, S. de M. B. Coral e outros poemas. São Paulo: Companhia das Letras, 2018. p. 17-42.

LOURENÇO. E. Para um retrato de Sophia. In: ANDRESEN, S. de M. B. Antologia. Lisboa: Moraes Editores, 1975. p. I-VIII.

SENA, J. Escritoras na literatura portuguesa do séc. XX. In: Estudos de literatura portuguesa III. Lisboa: Edições 70, 1988. p. 149153.

STEINER, G. Presenças reais: as artes do sentido. Tradução de Miguel Serras Pereira. Lisboa: Editorial Presença, 1993.

TAVARES, M. A. S. Contributo para uma biografia poética. In: ANDRESEN, S. de M. B. Obra poética. Porto: Assírio \& Alvim, 2015. p. 7-51. 
VATTIMO, G. O fim da modernidade: niilismo e hermenêutica na cultura pós-moderna. Tradução de Eduardo Brandão. São Paulo: Martins Fontes, 2002.

ZENITH, R. Uma cruz em Creta: a salvação sophiana. Colóquio/Letras, Lisboa, n. 176, p. 38-45, jan. 2011. 